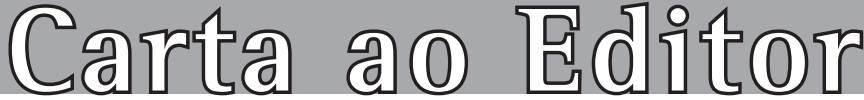

\section{0 sertão de Vicente Forte e sua vivente obra dedicada à medicina brasileira}

\author{
The fortitude of Vicente Forte and his living art dedicated to medicine in Brazil
}

\author{
Geraldo Roger Normando Júnior
}

\section{Ao editor:}

Se um dia permitissem-me falar sobre o cirurgião Vicente Forte, começaria por compará-lo a Guimarães Rosa. Certamente, perceberiam o quanto ele significou para a cirurgia brasileira. Em comum, ambos tinham a visão sertaneja do mundo: do sertão geográfico e do sertão das almas.

0 sertão geográfico que morava em Vicente era aquele em que não se esquivava de visitar os terrenos mais distantes para ensinar a nobre arte de operar. Dedicou-se a muitos temas, é certo, mas a traquéia foi o território onde conviveu bem à vontade; e ainda tirava nossos "grilos".

Neste aspecto, o ser tão humano de Vicente era o mesmo de Rosa, e quem lê suas obras percebe esse clamor pela humildade e pela caminhada ao vasto interior brasileiro. Entre tantas passagens do escritor, numa ele afirma o quanto é difícil a abordagem da perda, fervorosamente ratificada em um de seus famosos textos: "arriscado e conturbado é a gente se tirar das solidões fortificados". Define, claramente então, quão frágil é a virtuosidade frente à desgraça, o silêncio frente ao barulho, a paz frente à guerra e a morte frente à vida. São por esses meandros que passamos a rever nosso absolutismo sobre o que apalpamos, vemos e sentimos e, quando realmente conseguimos enxergar alguma luz, fosca, tal como a da partida de Vicente Forte, a lassidão devora a alma sertaneja tal como uma febre terçã.

No abril passado, ao ser aberto o peito de Vicente, viu-se que seu marca-passo já não era mais obedecido. 0 tambor que lá dentro batucava não mais repetia a mesma sincronia com o resto da orquestra orgânica e, quanto menos se esperava, uma notícia foi soprada por nossa floresta, alcançando o grande rio, o sertão (geográfico), o cerrado, os pampas, a serra e o mar, fazendo estremecer nossos ouvidos. Nossos músculos ficaram sem a bainha de actina. A placa motora não repolarizou e Vicente parou. Todos pararam. Foi uma tempestade miastênica. Todos choraram o choro da lembrança de quem, em vida, fez da ética, da moral e do saber, elementos propulsores da rotação da terra em torno de seu próprio eixo.

Dona Lílian não mais arfa como antes. Seu coração trilinda pelos cantos da casa, procurando sua outra parte perdida, e partida pela partida brusca e irremediável. Os meninos andam a esmo sussurrando no mesmo silêncio que a aranha tece a teia. Assim, sentenciam o que o pai foi: um nobre, vestido de simplicidade e calçado de solidariedade. Saibam, meninos! Só se acha o silêncio na alma dos júbilos. Saibam também que estamos de luto, contando histórias de um homem de tutano grosso. Nossos pulmões estão colapsados, por conseguinte, os tóraces esvaziados.

Como então sair dessa solidão tísica, que adentra nosso interior através de nossas vias aéreas, se o anjo crítico de nossa comunidade partiu sem deixar, sequer, seu novo endereço eletrônico? Além de órfãos, nossas asas ficaram mais curtas, e certamente nosso vôo será mais rasante, visto que Vicente era quem nos dava prumo, independente do rumo da rosa-dos-ventos.

E o forte da história do Forte foi o lançamento da pedra fundamental da Sociedade Brasileira de Cirurgia Torácica (SBCT, 1997), em que foi o primeiro Presidente. Sempre colocou a Sociedade Brasileira de Pneumologia e Tisiologia e a SBCT em "sua" canoa de idéias e fez seguir a remo no destino das ciências de Laennac e Sauerbruch. Quantas vezes se viu Vicente vivamente acendendo discussões com jovens e velhos nas salas de nossos congressos? Assim era sua estampa ideológica.

Agora, sem a fotografia do ideologista estampada na proa, "nossa" canoa segue sem remo, apenas no banzeiro. Embarcamos para nossos congressos com a certeza de que naquela cadeira da frente, sempre reservada ao crítico mais candente, só restará o vácuo. Ainda enlutados, perseguiremos instintivamente seu vulto, e relataremos suas histórias com a própria história que ele mesmo ajudou a construir na cirurgia brasileira, transformando aquela pedra rústica, o "Tórax do Brasil", numa obra polida com esmero e vigor.

0 Sertão de Vicente pertencia a um ser tão forte, que não há como deixar de reverenciá-lo. Na lápide desta lapidada pedra que tem o formato de um torso está escrito que além de fornecer o cinzel, Vicente ensinou-nos traquejo, o mesmo que usava em "suas" traquéias, para soerguer este segmento bíblico da cirurgia. Pôs-se, pois, a decodificar segredos que lembram os de "La Gioconda" de Leonardo da Vinci, e a buscar um vasto terreno para impor a especialidade ante as demais, o que lembra a astúcia napoleônica. Para isso, primeiro transformou a rugosidade da pedra em contornos semelhantes às paredes de "La Pedrera", de Gaudí. Empregou detalhes e brilhos nos arremates como um certo Michelangelo fez em sua "Pietá". Usou de expressões 
impressionantes, que reluziram como as "Ninféias" de Monet. Teve vitalidade que traduz os músculos e tendões de "0 Pensador", de Rodin, e pintou a parte superior do torso com as cores ensolaradas de um outro Vicente, o Van Gogh. No final, deu ao torso sua própria alma, como se fora um transplante autólogo.
Geraldo Roger Normando Júnior Chefe do Serviço de Cirurgia Torácica do Hospital Universitário João de Barros Barreto da Universidade Federal do Pará, Belém (PA) Brasil 